\title{
Rusproblemer hos eldre
}

\author{
Rus- og avhengighetsproblemer hos eldre er et økende problem, men lite påaktet i Norge. Vi trenger mer \\ kunnskap og kompetanse om eldres rusvaner og rusproblemer, både i kommunehelsetjenesten og \\ i spesialisthelsetjenesten.
}

Linn-Heidi Lunde
liheilu@hotmail.com

Rusmiddelbruken blant eldre er økende. Dette gjelder spesielt bruk av alkohol og vanedannende legemidler. Tall fra den store helseundersøkelsen i Nord-Trøndelag (HUNT) viser at andelen kvinner og menn som rapporterer problemer knyttet til alkohol, har økt fra 1995 til 2008, og aller mest i aldersgruppen 50-70 år (1). I rapporten Morgendagens eldre, som er basert på data fra en pågående studie om aldring (NorLAG-studien, Den norske studien om livsløp, aldring og generasjon) har man blant annet sett på alkoholvaner og alkoholbruk hos morgendagens eldre (2). Disse dataene tyder på et økende alkoholforbruk, spesielt blant middelaldrende og eldre kvinner med høyere utdanning. Morgendagens eldre vil ha andre alkoholvaner og et annet forhold til rusmidler enn dagens og tidligere generasjoners eldre, og mye tyder på at man drar med seg slike vaner inn $i$ alderdommen (2).

Bruken av reseptbelagte vanedannende legemidler øker med alderen og er særlig høy hos eldre kvinner. Tall fra Reseptregisteret fra perioden 2005-09 viser at eldre over 70 år får forskrevet store mengder beroligende medikamenter, søvnmedikamenter og ulike typer smertestillende (3). Rus- og avhengighetsproblemer hos eldre har alvorlige individuelle og samfunnsøkonomiske omkostninger i form av økt forekomst av kompliserte sykdomsforløp, skader og bruk av helsetjenester, inkludert sykehusinnleggelse (4). Aldersrelaterte endringer i fysiske, psykiske og sosiale forhold øker den eldres sårbarhet for negative virkninger av rusmidler $(4,5)$, men rusproblemer hos eldre er i stor grad underdiagnostisert og underbehandlet (5).

\section{Tverrfaglig spesialisert rusbehandling}

Rusreformen i 2004 har gitt personer med rusproblemer samme rett til helsehjelp som andre pasientgrupper. Tverrfaglig spesialisert behandling for rusmiddelavhengige er blitt en del av spesialisthelsetjenesten. I en rapport fra Helsedirektoratet om pasienter $i$ tverrfaglig spesialisert rusbehandling fremkommer det av oversikten over antall henvisninger gruppert etter alder at eldre fra 60 år og oppover er underrepresentert i tverrfaglig spesialisert behandling for rusmiddelavhengige (6).

Helse- og omsorgsdepartementet lanserte nylig stortingsmeldingen Se meg! En helhetlig rusmiddelpolitikk (7). Økningen i alkoholkonsum og bruk av vanedannende reseptbelagte legemidler i eldrebefolkningen er trukket frem som en særlig utfordring og bekymring. Meldingen oppfordrer til forsterket innsats, blant annet i form av kompetanseheving i helsetjenestene og økt forskning.

\section{Mangelfull avdekking og viderehenvisning}

I ulike internasjonale studier og rapporter er det pekt på at helsepersonell i mindre grad enn for yngre henviser eldre til spesialisert rusbehandling $(5,8)$. Det er mange og sammensatte forklaringer på hvorfor det er slik. Manglende videre henvisning kan ha sammenheng med underdiagnostisering og lav kunnskap om rus og avhengighetstilstander hos eldre $(5,8)$.

Symptomer på alkoholproblemer hos eldre kan være atypiske, slik som fall, akutt forvirring eller depresjon. Symptomene kan være maskert av samtidig somatisk eller psykiatrisk sykdom, noe som kompliserer avdekking og diagnostikk (5). Helsepersonell kan ha en oppfatning om at pasientens alkoholmisbruk og misbruk av vanedannende legemidler er forståelig sett på bakgrunn av vedkommendes livssituasjon, som for eksempel er preget av ensomhet eller tapsopplevelser (9). Det at mange eldre bor alene, kan også være en årsak til at rusproblemer ikke blir oppdaget (9). Eldre underrapporter også rusproblemer i større grad enn yngre, noe som kan skyldes at slike problemer er forbundet med større skam og skyldfølelse i eldre aldersgrupper (10). Helsepersonell kan kvie seg for å spørre om bruk av rusmidler, fordi det kan oppleves som en krenking av privatlivets fred (9).

Negative holdninger og stereotypier til aldring og eldre er også trukket frem $(5,8$, 9 ). Det er en utbredt oppfatning at eldre er mindre endringsvillige enn yngre og derfor ikke vil kunne nyttiggjøre seg behandling som har endring som mål (11). Dette til tross for god dokumentasjon på at eldre med rusproblemer profitterer vel så bra, om ikke bedre, på ulike former for psykologisk intervensjon som yngre (12).

\section{Bedre kartlegging og screening}

Mangel på egnede og hensiktsmessige kartleggingsinstrumenter for avdekking av rusproblemer hos eldre kan også være en forklaring på at denne pasientgruppen i liten grad blir henvist til spesialisert rusbehandling. Kartleggingsverktøyene må være brukervennlige og ikke ta for lang tid å gjennomføre (5). I en norsk studie fant man at allmennpraktiserende leger i liten grad bruker kartleggingsinstrumenter for å avdekke alkoholbruk hos sine pasienter (13). Studien viser at norske allmennleger i større grad intervenerer når pasientens alkoholproblemer blir synlige fremfor å prøve å avdekke disse i en tidligere fase.

Også andre faggrupper, deriblant sykepleiere, kan gjennomføre tiltak som screening og avdekking, noe som kan bidra til at man når bedre ut med tiltak $(14,15)$. I Helsedirektoratets veileder Fra bekymring til handling er det fremhevet at alle ansatte i helsetjenesten som er i posisjon til å oppdage et rusproblem bør gjøre noe med en bekymring (16). Hensiktsmessig kartlegging og diagnostisering er en forutsetning for å kunne vurdere om pasienten trenger hjelp i spesialisthelsetjenesten eller kan ha nytte av tiltak i kommunehelsetjenesten.

\section{Behov for forskning}

I Norge er det foreløpig lite forskning om alkoholproblemer og skadelig legemiddelbruk hos eldre. Helsedirektoratet anbefaler at det satses på tidlig intervensjon i sårbare grupper, og eldre fra 65 år og oppover er trukket frem som en slik gruppe (16). Tidlig avdekking og intervensjon ved rusproblemer hos eldre er også fremhevet som sentrale områder for videre forskning $(4,5$, 9). I en fersk rapport om bruk av alkohol og legemidler blant eldre i Norge, basert på 


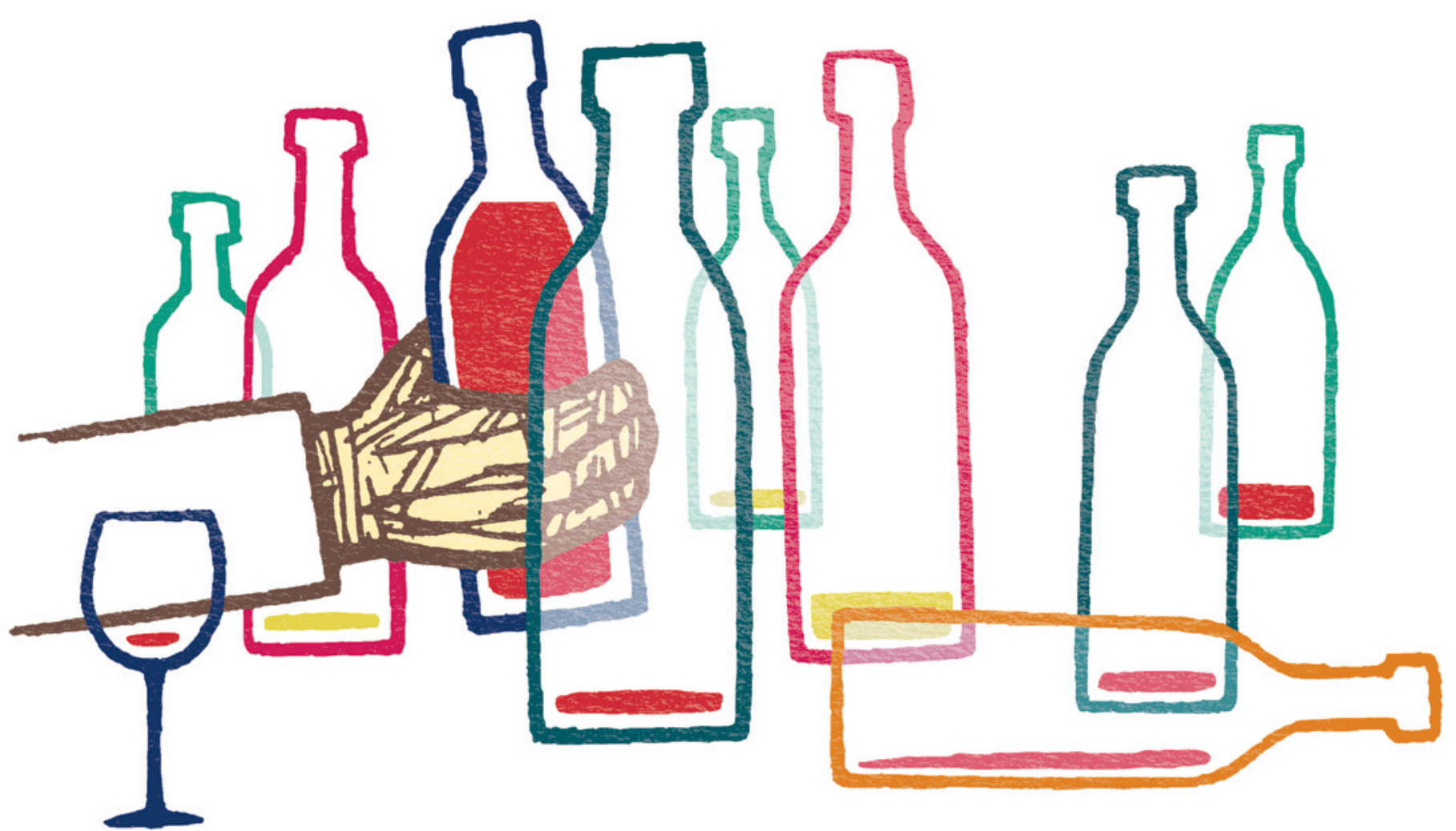

Illustrasjon @ Supernøtt popsløyd

data fra HUNT-studien, er en av hovedkonklusjonene at man bør legge vekt på utvikling og validering av screeningsinstrumenter som er tilpasset eldre (17).

\section{Tidlig intervensjon}

Ved Avdeling for rusmedisin planlegger vi et forskningsprosjekt i samarbeid med Det psykologiske fakultet ved Universitetet i Bergen om skadelig alkoholbruk hos eldre over 60 år. Vi tar bl.a. sikte på å validere kortversjonen av Alcohol Use Disorder Identification Test (AUDIT-C) og å tilpasse instrumentet til eldrebefolkningen $(18,19)$. Det er behov for flere studier for å evaluere bruk av AUDIT i eldrepopulasjoner, både på grunn av instrumentets lave sensitivitet hos eldre og behovet for mer hensiktsmessige grenseverdiskårer som tar hensyn til eldres reduserte alkoholtoleranse (20). Valideringsstudien skal gjennomføres på et utvalg av pasienter/personer som er i kontakt med kommunehelsetjenesten. Faktorer som virker henholdsvis hemmende og fremmende på implementering vil få spesiell oppmerksomhet.

Linn-Heidi Lunde (f. 1959) er førsteamanuensis i klinisk psykologi ved Universitetet i Bergen og psykologspesialist ved Avdeling for rusmedisin, Haukeland universitetssykehus.

Forfatter har fylt ut ICMJE-skjemaet og oppgir ingen interessekonflikter.
Litteratur

1. Krokstad S, Skjei MK. Folkehelse i endring. Helseundersøkelsen i Nord-Trøndelag. HUNT 1 (1984-86). HUNT 2 (1995-97). HUNT 3 (2006-08). Trondheim: HUNT forskningssenter, 2011.

2. Clausen SE, Valset K, Blekesaune M et al. Helsevaner blant dagens og morgendagens eldre. I: Slagsvold B, Solem PE, red. Morgendagens eldre. En sammenligning av verdier, holdninger og atferd blant middelaldrende og eldre. NOVArapport nr.11/05. Oslo: Norsk institutt for forskning om oppvekst, velferd og aldring, 2005: $131-53$.

3. Folkehelseinstituttet. Reseptregistere 2005-2009. Vanedannede legemidler. Legemiddelstatistikk 2010. Oslo: Folkehelseinstituttet, 2010.

4. Hallgren M, Høgberg P, Andreasson S. Alcohol consumption among elderly European Union citizens. Stockholm: Swedish National Institute of Public Health, 2009

5. Crome I, Dar K, Janikiewicz S et al. red. Our invisible addicts. London: Royal College of Psychiatrists, 2011

6. Helsedirektoratet. Pasienter i tverrfaglig spesialisert rusbehandling 2010. Rapport IS-1956, 2011. Oslo: Helsedirektoratet, 2011.

7. St.meld. nr. 30 (2011-2012). Se meg! En helhetlig rusmiddelpolitikk.

8. O'Connell H, Chin AV, Cunningham $\mathrm{C}$ et al. Alcoho use disorders in elderly people-redefining an age old problem in old age. BMJ 2003; 327: 664-7.

9. Frydenlund R. Eldre, alkohol og legemiddelbruk. En kunnskapsoppsummering. Oslo: Kompetansesenter rus - Oslo, Oslo kommune, 2011.

10. Dar K. Alcohol use disorders in elderly people: fact or fiction? Adv Psychiatr Treat 2006: 12: 173-81.

11. Laidlaw K, Thompson LW. Dick-Siskin L et al. Cognitive behaviour therapy with older people. Chichester: Wiley, 2003: 118-29.

12 Moy I, Crome P, Crome I et al. Systematic and narrative review of treatment for older people with substance problems. Eur Geriatr Med 2011; 2 212-36

13. Nygaard P, Paschall MJ, Aasland OG et al. Use and barriers to use of screening and brief interventions for alcohol problems among Norwegian general practitioners. Alcohol Alcohol 2010; 45: 207-12.

14. Baklien B, Pape H, Rossow I et al. Regionprosjektet - nyttig forebygging? Evaluering av et pilotprosjekt om lokalbasert rusforebygging, nr. 6/2007. Oslo: Statens institutt for rusmiddelforskning. 2007

15. Babor TF, Higgins-Biddle JC, Saunders JB et al. The alcohol use disorders identification test. Guidelines for use in primary care. 2. utg. Genève: World Health Organization, 2001

16. Backlund S, Enstad F. Frøyland K et al. Fra bekymring til handling. En veileder om tidlig intervensjon på rusområdet. Oslo: Helsedirektoratet, 2009

17. Støver M, Bratberg G, Nordfjærn T et al. Bruk av alkohol og medikamenter blant eldre $(60+)$ i Norge. Trondheim: Helseunders $ø$ kelsen i NordTrøndelag. HUNT forskningssenter, Norges teknisk-naturvitenskapelige universitet, 2012.

18. Saunders JB, Aasland OG, Babor TF et al. Development of the Alcohol Use Disorders Identification Test (AUDIT): WHO Collaborative Project on Early Detection of Persons with Harmful Alcohol Consumption-II. Addiction 1993; 88: 791-804.

19. Towers A, Stephens C, Dulin P et al. Estimating older hazardous and binge drinking prevalence using AUDIT-C and AUDIT-3 thresholds specific to older adults. Drug Alcohol Depend 2011; 117: $211-8$.

20. Meneses-Gaya C, Zuardi AW, Loureiro SR et al. Alcohol use Disorder Identification Test (AUDIT): an updated systematic review of psychometric properties. Psychol Neurosci 2009; 2: 83-7.

Mottatt 11.10. 2012, første revisjon innsendt 29.10 2012, godkjent 22.11. 2012. Medisinsk redaktør Petter Gjersvik.

Podkast på www.tidsskriftet.no 